\title{
PENGARUH SPIRITUAL LEADERSHIP TERHADAP DISIPLIN KERJAPERAWAT DI RUMAH SAKIT IBU DAN ANAK AISYIYAH SAMARINDA
}

\author{
Enok Sureskiarti $^{1}$, Vina Avioleta ${ }^{2}$ \\ ${ }^{1,2}$ Universitas Muhammadiyah Kalimantan Timur \\ Email : es202@umkt.ac.id
}

\begin{abstract}
ABSTRAK
Disiplin merupakan suatu kondisi atau sikap hormat yang ada pada diri karyawan terhadap peraturan dan ketetapan perusahaan. Sedangkan kerja adalah perbuatan melakukan sesuatu kegiatan yang bertujuan mendapatkan hasil. Dengan demikian bila peraturan atau ketetapan yang ada dalam perusahan itu diabaikan atau sering dilanggar, maka karyawan mempunyai disiplin kerja yang buruk, sebaliknya bila karyawan tunduk pada ketetapan perusahan, menggambarkan adanya kondisi disiplin yang baik. Salah satu yang berkaitan dengan efektifitas sebuah kepemimpinan ditempat kerja tidak terlepas dari nilai spiritual. Spiritual leadership adalah kepemimpinan yang membawa keduniawian kepada dimensi keilahian (spiritual). Untuk mengetahui pengaruh spiritual leadership terhadap disiplin kerja perawat di RSIA Aisyiyah Samarinda. Jenis penelitian ini adalah Quasi Eksperimen dengan Pretest-Posttest Desigen with control group. Populasi penelitian ini sebanyak 22 responden. Analisa meliputi analisa univariat dan bivariat menggunakan korelasi Pairred t-test dan independen t-test. Hasil analisa bivariat korelasi Pairred T-Test dipeloleh hasil p-value = $0.005<0.05$, dan untuk hasil $0.007<0.05$. Dari hasil penelitian dapat disimpulkan bahwa ada pengaruh spiritual leadership terhadap disiplin kerja perawat
\end{abstract}

Kata Kunci : Disiplin Kerja, Spiritual Leadership, Perawat 


\section{ABSTRACT}

Discipline is a condition or respect that is in the employee's own rules and regulations. While work is the act of doing something that aims to get results. Thus, if the rules or provisions in the company are ignored or often violated, then the employee has a poor work discipline. Conversely, if the employee is subject to the provisions of the company, it describes the existence of a good discipline condition. One that is related to the effectiveness of a leadership in the workplace is inseparable from spiritual values. Spiritual leadership is leadership that brings worldliness to the dimension of divinity (spiritual). To find out the influence of spiritual leadership on nurses' work discipline at RSIA Aisyiyah Samarinda. This type of research is Quasi Experiment with Pretest-Posttest Desigen with control group. The population of this study were 22 respondents. Analysis includes univariate and bivariate analysis using paired t-test correlation and independent t-test. The results of the bivariate analysis of the Pairred T-Test correlation obtained the results of p-value = $0.005<0.05$, and for the results of $0.007<0.05$. From the results of the study it can be concluded that there is an influence of spiritual leadership on nurse work discipline

Keywords: Work Discipline, Spiritual Leadership, Nurses

\section{PENDAHULUAN}

Pelayanan keperawatan dirumah sakit tidak dapat dipisahkan dari pelayanan kesehatan yang mempunyai kontribusi yang sangat penting untuk menentukan kualitas pelayanan. Perawat sebagai salah satu sumber daya manusia yang terpenting dirumah sakit, memberikan pelayanan yang terus menerus kepada pasien selama 24 jam setiap hari. Suatu pelayanan itu sendiri dibentuk dari berdasarkan 5 prinsip Survice Quality yaitu kecepatan, ketepatan, keamanan, keramahan, dan kenyamanan (Anjaryani, 2009). Aspek kekuatan Sumber Daya Manusia (SDM) dapat tercermin pada sikap dan perilaku disiplin, sebab dalam sebuah organisasi, disiplin adalah sesuatu yang besar manfaatnya, baik bagi kepentingan organisasi tersebut maupun bagi karyawanya. Untuk mendapatkan hasil kinerja yang baik dibutuhkan disiplin kerja yang tinggi, sebab perawat yang tidak disiplin dalam melaksanakan pekerjaannya, maka ada kemungkinan terjadinya penyelewengan karena karyawan lalai dalam melaksankan tugasnya. Sutrisno (2011) menyatakan bahwa disiplin menunjukan suatu kondisi atau sikap hormat yang ada pada diri karyawan terhadap peraturan dan ketetapan perusahaan. Sedangkan kerja adalah perbuatan melakukan sesuatu kegiatan yang bertujuan mendapatkan hasil (Ishak, 2004:8). Dengan demikian bila peraturan atau ketetapan yang ada dalam perusahan itu diabaikan atau sering dilanggar, maka karyawan mempunyai disiplin kerja yang buruk, sebaliknya bila karyawan tunduk pada ketetapan perusahan, menggambarkan adanya kondisi disiplin yang baik.

Rumah sakit membutuhkan pemimpin yakni sebagai faktor penting yang sangat baik menentukan keberhasilan suatu organisasi. Dalam kepemimpinan suatu organisasi yang baik dapat meningkatkan kinerja karyawannya dan demikian begitu pula sebaiknya (Suliyno, 2009). Peran 
kepemimpinan yang sangat penting bagi pencapaian visi, misi, dan tujuan suatu rumah sakit dicapai semata-mata untuk tercapainya suatu tujuan sebagai faktor terpenting dalam keberhasilan atau kegagalan dalam suatu rumah sakit. Kepemimpinan adalah kemampuan memberi inspirasi kepada orang lain untuk berkeja sama sebagai suatu kelompok, agar dapat mencapai suatu tujuan umum. Salah satu hal yang berkaitan dengan efektifitas sebuah kepemimpinan di tempat kerja tidak terlepas dari nilai spiritual tertentu. Kebutuhan spiritual di tempat kerja akan memberikan pengaruh positif pada kesehatan secara fisik dan psikologis (Fry, L. W; 2005:2).

Selain itu diperlukan Kepemimpinan spiritual kepemimpinan yang membawa dimensi spiritual (keilaihian), (Tobroni, 2010:5). Teori kepemimpinan spiritual dikembangakan dengan menggunakan sebuah model motivasi intrinsic yang menggabungkan adanya visi, harapan/keyakinan, dan cinta altruistic. Spiritual Leadership diyakini sebagai solusi terhadap krisis kepemimpinan saat ini (Tobroni, 2010:6). Selain itu, Spiritual Leadership juga dipandang menjadi sebuah paradigma dalam perubahan dan tranformasi organisasi yang pada hakekatnya diciptakan untuk membentuk sebuah motivasi intrinsik dari individu tersebut. Giacalone, Jurkiewicz \& Fry menyatakan Spiritual Leadership dapat pula dipandang sebagai sebuah upaya kekuatan memotivasi yang memungkinkan orang lain untuk menjadi lebih baik, berenergi dan terhubung atau terikat dengan pekerjaannya. Hal ini menjadi sebuah dasar kekuatan untuk menterjemahkan spiritual survival ini menjadi sebuah feelings of attraction, ketertarikan dan caring terhadap pekerjaan maupun orang dalam lingkungan kerja untuk menjadi lebih berkomitmen, produktif dalam perilaku berorganisasi.

Rumah Sakit Ibu dan Anak Aisyiyah Samarinda didirikan pada tanggal 7 Juli 1967 berdasarkan dengan surat keputusan Menteri Kesehatan RI No. 330/P.Kes/I.0/73. Pada tanggal 24 Rabiul Awal 1387 Masehi, Rumah Sakit bersalin diresmikan oleh Gubernur Kalimantan Timur. Dengan nama Rumah Sakit Aisyiyah Samarinda, yang ditetapkan berdasarkan hasil rapat gabungan antara pengurus Muhammadiyah dan Aisyiyah Wilayah maupun Daerah kemudian diputuskan untuk menyerahkan pengelolaan Rumah Sakit bersalin tersebut kepada Aisyiyah Wilayah Kalimantan Timur. Sejak didirikan dan dioperasikan pada Juni 1967 sebagai Rumah Sakit Bersalin dan pada tahun 1992 berubah menjadi Rumah Sakit Khusus Ibu dan Anak telah mengalami perubahan dan perkembangan yang dipimpin oleh Bapak dr. H. Agus Sukaca, M.Kes sampai tahun 1992 dan bapak dr. H. Nur Ashrien Husain sampai bulan April 2004. Kemudian dipimpin oleh dr. H. Mudamin sampai Januari 2011. Di bawah kepemimpinan dr. Nurul Karti Handayani, Sp.OG (periode 2011 s.d sekarang). Kekhususan yang dipilih adalah 2 (dua) spesialisasi, yakni Kebidanan dan Penyakit Kandungan serta Penyakit Anak. Nama yang dipilih adalah Rumah Sakit Khusus Ibu dan Anak.

Berdasarkan studi pendahuluan yang dilakukan peneliti di RSIA Aisyiyah Samarinda tanggal 22 Desember 2017 didapatkan hasil dari Sry Yana S.Kep bagian kepegawaian mendapatkan hasil keseluruhan jumlah perawat yang bekerja 
di RSIA Aisyiyah Samarinda sebanyak 22 perawat. Latar pendidikan perawat D3 sejumlah 20 orang dan profesi sarjana keperawatan berjumlah 2 orang perawat. Dari hasil wawancara mengenai disiplin kerja kepada 5 orang perawat dari 22 orang perawat di ruang keperawatan anak 3 diantaranya mengatakan bahwa masih sering kali datang tidak tepat waktu sesuai jam kerja yang ditantukan, dan 2 orang perawat mengatakan selalu datang tepat waktu. Kemudian untuk kepatuhan terhadap peraturan 3 mengatakan tidak selalu mengikuti peraturan yang ada karena terkadang tidak memakai atribut lengkap dan seragam yang ditentukan, sedangkan 2 diantaranya selalu mengikuti peraturan yang sudah ditetapkan. Untuk kegiatan kerohanian selalu diberikan pihak RSIA Aisiyah untuk meningkatkan pengetahuan agama bagi seluruh karyawan terutama Perawat. Berdasarkan dari data yang didapat peneliti ingin membuktikan untuk meneliti, pengaruh spiritual leadership terhadap disiplin kerja perawat di RSIA Aisyiyah Samarinda.

\section{METODE PENELITIAN}

Rancangan penelitian yaitu Quasi Eksperimen. Desain penelitian yang digunakan yaitu kuantitatif dengan pre and post test with control group. Dalam penelitian ini yang menjadi populasi adalah seluruh perawat yang ada di
RSIA Aisyiyah Samarinda yang terdiri dari 22 perawat di ruang keperawatan anak. Penelitian ini menggunakan total sampling dengan subyek penelitian yang diambil perawat yang bekerja di RSIA Aisyiyah Samarinda. Penelitian ini terdiri dari 11 perawata sebagai kelompok Intervensi dan 11 perawat sebagai kelompok control. Penelitian ini dilakukan di RSIA Aisyiyah yang beralamat di jalan Pangeran Hidayatullah No. 64 pelabuhan, kota Samarinda, Kalimantan Timur kode pos 75112. Penelitian dilaksanakan pada bulan 4 Juni 2018 - 5 Juli 2018.Sebelum penelitian dilakukan terlebih dahulu dilakukan proses perijinan ke RSIA Aisyiyah, setelah mendapatkan ijin dari pihat Rumah Sakit baru peneliti melakukan penelitian. Untuk mengetahui pengaruh Spiritual Leadership terhadap disiplin kerja perawat menggunakan uji statistic pairret t-test dan independen $t$ test dengan $\alpha=0,05$.

\section{HASIL DAN PEMBAHASAN HASIL}

a. Karakteristik Responden

Karakteristik perawat dalam penelitian ini meliputi umur, jenis kelamin, tingkat pendidikan, dan lama kerja seperti pada tabel 4.1 berikut ini :

Tabel 4.1 karakteristik responden pada kelompok intervensi dan kelompok kontrol di RSIA Aisyiyah Samarinda

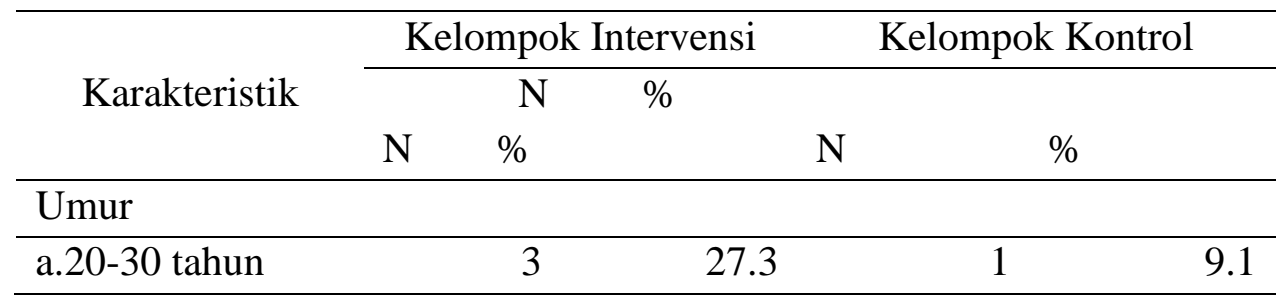




\begin{tabular}{lrrrr} 
b. $31-40$ tahun & 6 & 54.5 & 9 & 81.8 \\
\hline c. $>40$ tahun & 2 & 18.2 & 1 & 9.1 \\
\hline Total & 11 & 100 & 11 & 100 \\
\hline Jenis Kelamin & & & & \\
\hline a.Laki-Laki & 1 & 9.1 & 1 & 9.1 \\
\hline b.Perempuan & 10 & 90.9 & 10 & 90.9 \\
\hline Total & 11 & 100 & 11 & 100 \\
\hline
\end{tabular}

Tingkat

Pendidikan

\begin{tabular}{lrrrr}
\hline a.D3 & & & & \\
Keperawatan & 10 & 90.9 & 10 & 90.9 \\
\hline b.S1 Keperawatan & 1 & 9.1 & 1 & 9.1 \\
\hline Total & 11 & 100 & 11 & 100 \\
\hline Lama masa kerja & & & & \\
\hline a.1-10 tahun & 6 & 54.4 & 7 & 63.6 \\
\hline b.11-20 tahun & 4 & 36.4 & 3 & 36.4 \\
\hline c.>20 tahun & 1 & 9.1 & 1 & 9.1 \\
\hline Total & 11 & 100 & 11 & 100 \\
\hline
\end{tabular}

Disiplin kerja perawat sebelum diterapkan spiritual leadership pada tabel 4.2 diatas menunjukkan bahwa nilai rata-rata disiplin kerja perawat sebelum diterapkan spiritual leadership pada kelompok intervensi adalah 56,27, Nilai standar deviasi 3,319, dengan nilai minumum 52 dan nilai maksimum 61, nilai lower 54,04 dan uper 58,50. Sedangkan nilai untuk kelompok sebagai berikut nilai rata-rata disiplin kerja perawat 54,45, nilai standar deviasi 3,560 dengan nilai minimum 49 serta nilai maksimum 61, nilai lower 52,06 dan uper 56,85 .

a. Pengaruh sesudah Intervensi pada kelompok intervensi dan kelompok kontrol, dilihat pada tabel 4.3.

Tabel 4.3

Gambaran Perbedaan Disiplin Kerja Perawat Sesudah Penerapan Spiritual Leadership pada Kelompok Intervensi dan Kelompok Kontrol di RSIA Aisyiyah Samarinda, 2018 $(\mathrm{N} 1, \mathrm{~N} 2=22)$

\begin{tabular}{lllllll}
\hline \multirow{2}{*}{ Kelompok } & \multirow{2}{*}{ mean } & \multirow{2}{*}{ SD } & \multirow{2}{*}{ Min-Max } & \multicolumn{2}{c}{$95 \%$ CI } \\
\cline { 5 - 7 } & & & & Lower & Upper \\
\hline Intervensi & 58,36 & 2,580 & $55-62$ & 56,63 & & 60.1 \\
\hline Kontrol & 54,64 & 3,202 & $50-61$ & 52,49 & 56,79 \\
\hline
\end{tabular}


Berdasarkan hasil tabel 4.3 disiplin kerja perawat sesudah diterapkan spiritual leadership menunjukkan bahwa nilai ratarata kelompok intervensi adalah 58,36 nilai standar deviasi 2,580 dengan nilai minumum 55 dan nilai maksimum 62 , nilai lower 56,63 dan uper 60,10. Sedangkan nilai untuk kelompok kontrol sebagai berikut nilai rata-rata disiplin kerja perawat 54,64 nilai standar deviasi 3,202 dengan nilai minimum 50 serta nilai maksimum 61, nilai lower 52,49 dan uper 56,79 .

a. Analisa Bivariat

Analisa Bivariat digunakan untuk mengetahui adanya pengaruh Penerapan
Spiritual Leadership (Variabel Independen) terhadap disiplin kerja perawat (Variabel Dependen).

Setelah dilakukan uji normalitas diketahui sebaran data berdistribusi normal oleh karena itu analisa data yang digunakan pada penelitian ini adalah paired $t$ test. Uji pairred t test adalah uji yang digunakan untuk mengetahui ada atau tidaknya pengaruh penerapan spiritual leadership terhadap peningkatan disiplin kerja perawat di RSIA Aisyiyah Samarinda. Pada bagian ini akan diperlihatkan hasil outputnya pada table ini adalah:

Tabel 4.4 Pairred T Test Statistik Gambaran perbedaan disiplin kerja perawat Pada Kelompok Intervensi dan Kelompok Kontrol sebelum dan sesudah penerapan Spiritual Leadership di RSIA Aisyiyah Samarinda, $2018(\mathrm{~N}=11)$

\begin{tabular}{|c|c|c|c|c|}
\hline Variabel & $\mathbf{N}$ & Mean & Selisih & P Value \\
\hline Pre Test Intervensi & \multirow{2}{*}{11} & 56,27 & \multirow{2}{*}{$-2,091$} & \multirow{2}{*}{0,005} \\
\hline Post Test Intervensi & & 58,36 & & \\
\hline Pre Test Kontrol & \multirow{2}{*}{11} & 54,45 & \multirow{2}{*}{$-0,182$} & \multirow{2}{*}{0,703} \\
\hline Post Test Kontrol & & 54,64 & & \\
\hline
\end{tabular}

Berdasarkan, tabel 4.4 terlihat bahwa dari 11 responden menunjukan bahwa nilai rata-rata disiplin kerja perawat dalam pre test intervensi setelah diberikan penerapan spiritual leadership untuk disiplin kerja dengan nilai 56,27 dan post test intervensi 58,38 nilai selisih $-2,091$. Sedangkan untuk pre test kelompok kontrol 54,45 dan post test kelompok kontrol 56,64 nilai selisih -0,182.

Didapatkan selisih nilai 0.000 , dan $0.005<0.05$, sehingga dapat disimpulkan bahwa H0 ditolak yang berarti terdapat pengaruh penerapan spiritual leadership terhadap disiplin kerja perawat sebelum dan sesudah diberikannya penerapan spiritual leadership. Sedangkan pada kelompok kontrol diperoleh $\mathrm{p}$ value = 0,703>0,05 sehingga H0 diterima maka tidak ada perbedaan yang bermakna antara sebelum dan sesudah pada kelompok kontrol yang tidak dilakukan penerapan spiritual leadership. 


\section{PEMBAHASAN}

1. Karakteristik Responden

a. Umur

Bedasarkan tabel 4.1 diperoleh karakteristik bahwa responden dalam penelitian pada kelompok intervensi dan kelompok kontrol mayoritas berumur 31-40 tahun 6 responden $(54,5 \%), 9$ responden $(81,8)$. Rentang umur 30-40 tahun termasuk rentang umur produktif yang bisa bekerja secara optimal. Seseorang dapat melakukan pekerjaan dan tugas dengan tingkat produktifitas tinggi pada umur 3040 tahun, hal ini berpengaruh terhadap kinerja seseorang.

Menurut Robbins (2018) faktor umur memang merupakan variabel dari suatau individu yang pada dasarnya semakin bertambah umur maka akan bertambah pula kedewasaannya dalam bertindak. Tingkat pertumbuhan dan perkembangan seseorang secara fisik, sosial, dan psikologis yang dapat dilihat dari bertambahnya umur, hal ini berpengaruh terhadap peningkatan kemampuan individu secara motorik maupun psikologis yang mempengaruhi tingkat kedewasaan sesuai dengan tumbuh kembangnya.

Hal tersebut sejalan dengan penelitian dari ( Sureskiarti, 2015) pada usia diantara 30-40 tahun memiliki kinerja yang optimal dibanding dengan seseorang yang berumur > 50 tahun karena pada umur > 50 tahun kemampuan psikomotoriknya sudah mengalami penurunan pada umumnya spiritualitas mulai terbentuk, karena pada usia ini seseorang sudah menemukan jati diri yang sebenarnya dan mampunyai tugas dan tanggung jawab dalam keluarga sehingga lebih mendekatkan diri pada nilai-nilai altruistik yang terkandung dalam spiritualitas.

Peneliti berasumsi bahwa pada usia ini kemampuan dan relasi yang dimiliki oleh seseorang sedang berada dalam usia puncak, karena umur 30-40 tahun sudah termasuk rentang umur produktif yang bisa bekerja secara optimal.

a. Jenis Kelamin

Berdasarkan tabel 4.1 diperoleh bahwa mayoritas responden dalam penelitian pada kelompok intervensi dan kelompok kontrol jenis kelamin perempuan sama yang berjumlah 10 responden $(90,9 \%)$ dan jenis kelamin laki-laki sama untuk kelompok intervensi dan kelompok kontrol berjumlah 2 responden $(9,1 \%)$. Hasil penelitian ini menggambarkan bahwa sebagian besar responden berjenis kelamin perempuan, menurut ( Handoko, 2008) biasanya kaum perempuan mempunyai sifat ramah, tekun, disiplin, dan teliti dalam melaksankan asuhan keperawatan. Seorang perawat dituntut untuk memiliki rasa empati, tekun, teliti serta mempunyai sifat caring dalam memberikan pelayanan keperawatan. Sifat-sifat dominan yang dimiliki perempuan tersebut 
dapat menunjang pelayanan yang diberikan kepada pasien sehingga menjadi alasan lebih banyak perawat berjenis kelamin perempuan dibandingkan laki-laki. Perempuan memiliki sifat caring, raa empati, tekun, teliti dan disiplin yang tinggi yang terdapat pada nilai-nilai altruistik spiritual leadership diantaranya adalah sifat caring (Tabroni, 2010). Peneliti berasumsi bahwa perempuan dan laki-laki pada dasarnya sama saja tetapi ada sisi yang dimana terkadang perempuan lebih memiliki rasa empati, kesabaran dan kelembutan hati yang tinggi.

Hasil ini sejalan dengan hasil penelitian dari ( Yudaningsih, 2016,4:3) yang menggambarkan sebagian besar responden berjenis kelamin perempuan (85\%), responden penelitian tersebut menunjukkan bahwa pekerjaan perawat masih banyak diminati oleh perempuan dibandingkankan laki-laki, karena sebagai seorang perawat juga harus memerlukan sifat sabar, lemah lembut, giat dan penenuh kasih sayang oleh karena itu mayoritas masih diminati perempuan.

b. Tingkat Pendidikan

Berdasarkan tabel 4.1 diperoleh hasil bahwa mayoritas tingkat pendidikan responden pada kelompok intervensi D3 keperawatan 10 responden $(90,9 \%), \quad \mathrm{S} 1 \quad$ keperawatan 1 responden $(9,1 \%)$. Pada kelompok kontrol tingkat pendidikan D3 keperawatan 11 responden $(100,0)$.
Pendidikan adalah pembelajaran, pengetahuan, keterampilan, dan kebiasaan yang diberikan dari generasi kegenerasi berikutnya melalui proses pembelajaran, pelatihan, atau penelitian (Ilyas, 2002). Hasil ini sejalan dengan penelitian (Arifuddin, 2015:1) bahwa perawat memiliki tingkat pendidikan yang tinggi yaitu D3 sebanyak $76,8 \%$ dan S1 sebanyak 23,2\% maka semakin tinggi tingkat pendidikannya semakin banyak pengetahuan yang dapat menujunjang pekerjaanya sehingga kinerjanya cukup walaupun beban kerjanya berlebihan, tingkat pendidikan

Peneliti berpendapat untuk mewujudkan rumah sakit yang berkualitas maka harus memiliki perawat yang kompeten dalam ilmu keperawatan dengan tingkat pendidikan yang tinggi, semakin tinggi tingkat pendidikan maka semakin sistematis dari cara berfikirnya sehingga dapat meningkatkan kualitas dalam bekerja.

c. Masa kerja

Berdasarkan tabel 4.1 diperoleh bahwa responden dalam lama masa kerja pada kelompok intervensi 110 tahun berjumlah 6 responden $(54,5 \%)$, dan kelompok kontrol 110 tahun 7 responden $(63,3 \%)$. Masa kerja dihubungkan dengan pengalaman seseorang dalam menjalani bidang pekerjaan yang ditekuni. Menurut (Robbins, 2018) Masa kerja dikaitkan dengan hubungan senioritas atau anggapan 
bahwa semakin lama seseorang bekerja semakin lebih berpengalaman dan berpengaruh terhadap produktivitas kerja. Perawat yang baru bekerja berbeda dengan perawat yang sudah lama bekerja karena pengalaman yang dimiliki lebih banyak perawat yang memiliki pengalaman kerja lebih lama. Pengalaman masa kerja yang berbeda dari tiap perawat dapat menyebabkan kemampuan yang berbeda pula dalam memecahkan masalah. Dengan masa kerja yang relatif lama dapat membangun suatu budaya organisasi berdasarkan nilai-nilai altruistik, namun jika masa kerja perawat masih belum lama akan menyebabkan tuntutan pemenuhan kebutuhan yang masih kurang.

Hal tersebut sejalan dengan penelitian ( Mardatillh, 2017) pekerja yang telah diatas 5 tahun biasanya memiliki tingkat kejenuhan yang lebih tinggi dari pada pekerjaan yang baru bekerja, sehingga adanya tingkat kejenuhan tersebut dapat meningkatkan rasa malas dalam melakukan pendokumentasian asuhan keperawatan.

Peneliti berpendapat bahwa dalam masa kerja yang relatif lama akan dapat meningkatkan pengalaman yang cukup kompeten dalam masa kerja yang lebih baik sehingga semakin lama masa kerja semakin banyak pula perkembangan yang diikuti terhadap kemajuan rumah sakit.

\section{Analisa Bivariat}

Pengaruh penerapan spiritual leadership terhadap disiplin kerja perawat di RSIA Aisyiyah Samarinda setelah diberikan penerapan spiritual leadership selama 2 hari, dari hasil rata-rata pre test intervensi diberikan penerapan spiriual leadership disiplin kerja yaitu 56,27 dan post test intervensi yaitu 58,36 sedangkan, hasil rata-rata dari pre test kontrol yang tidak diberikan penerapan spiritual yaitu 54,45 dan untuk post test yaitu 56,64. Dari data yang didapat terdapat peningkatan antara nilai rata-rata pre test intervensi dan post test intervensi yang diberikan perlakuan, dan untuk pre test kontrol dan post test kontrol juga terdapat peningkatan walaupun tidak diberikan penerapan spiritual leadership.

Berdasarkan hasil uji bivariat dengan menggunakan uji paired $t$ test dan independent t-test dari 22 responden yang terbagi menjadi kelompok intervensi dan kelompok kontrol, didapatkan hasil analisa bivariat dengan taraf signifikan (p) $5 \%$ didapatkan hasil sig, (2-tailed) nilai (p) pada kelompok intervensi sebelum dan sesudah diberikan penerapan spiritual leadership yaitu 0,005 dan $\alpha=$ 0,05 nilai $\mathrm{p}$ value < yang berarti ada perbedaan nilai rata-rata sebelum dan sesudah diterapkan spiritual leadership dengan kata lain, penerapan spiritual leadership berpengaruh terhadap disiplin kerja perawat.

Pada kelompok kontrol nilai rata-rata disiplin kerja perawat untuk pre test berdasarkan hasil uji statistik nilai $\mathrm{p}$ value $=0,703$ yang berarti $p$ value $>$ 0,05 Ho diterima sehingga tidak ada 
perbedaan yang signifikan nilai ratarata disiplin kerja perawat sebelum dilakukan penerapan spiritual leadership dengan setelah dilakukan penerapan spiritual leadership pada kelompok kontrol di RSIA Aisyiyah Samarinda.

Hal tersebut sejalan dengan penelitian (Sureskiarti, 2015) nilai rata-rata kinerja perawat dalam melakukan asuhan keperawatan pada kelompok intervensi sebelum diberikan penerapan spiritual leadership adalah 86 dengan nilai minimum 80 dan nilai maksimum 90. Nilai rata-rata kinerja perawat setelah dilakukan penerapan spiritual leadership adalah 115,63 dengan nilai minimum 99 dan nilai maksimum 128. Dengan $p$ value = $0,001<\alpha$, terdapat kesimpulan bahwa ada peningkatan yang bermakna setelah dilakukan penerapan spiritual leadership terhadap kinerja perawat dalam melakukan asuhan keperawatan di Rumah Daerah H.DR, Soewondo Kendal.

Secara etiomologis disiplin berasal dari bahasa inggris "disciple" yang berarti pengikut atau panutan pengajaran, latihan dan sebagainya. Disiplin merupakan suatu keadaan tertentu dimana orang-orang yang tergabung dalam organisasi tunduk pada peraturan-peraturan yang ada dengan rasa senang hati. Sedangkan kerja adalah segala aktivitas manusia yang dilakukan untuk mencapai tujuan yang telah ditetapkan (Martono, 2008:125).

Disiplin kerja merupakan salah satu alat yang digunakan para manager untuk berkomunikasi dengan dengan pegawai agar mereka bersedia untuk mengubah suatu perilaku serta sebagai suatu upaya untuk meningkatkan kesadaran dan kesedian seseorang mentaati semua peraturan dan normanorma yang berlaku. Menurut (Hasibuan, 2012:194), banyak indikator yang mempengaruhi tingkat kedisiplinan seseorang pegawai, diantaranya, tujuan dan kemampuan, teladan kepemimpinan, balas jasa, keadilan, wasket, sanksi hukuman, ketegasan dan hubungan kemanusiaan.

Brigma (1994) dalam Astuti (2012:2) menyarankan bahwa disiplin kerja merupakan suatu sikap dan perilaku, dimana pembentukan perilaku jika dilihat dari formula Kurt Lewin yaitu interaksi antara faktor kepribadian dan faktor lingkungan.

Kebutuhan spiritual di tempat kerja akan memberikan pengaruh positif pada kesehatan fisik dan psikologis (Fly, L. W : 2005). Menurut (Tjahjono, dalam Tabroni 2010:5) spiritial leadership disebut sebagai kepemimpinan yang lebih mendasar pada iman dan hati nurani dalam kualitas kepemimpinan yang membersihkan hati, memberi, melayani, mencerahkan, dan menenangkan jiwa berdasarkan semangat syukur dan kasih. Tujuan spiritual leadership merupakan salah satu upaya memotivasi memberikan inspirasi pekerja berdasarkan nilai altruistik (altruistic value) guna menghasilkan motivasi, komitmen, dan produktivitas, sehingga seorang pemimpin mampu memotivasi dirinya dan orang lain untuk mencapai tujuan organisasi (Fly LW, 2005:2). 
Sedangkan, manfaat penerapan spiritual leadership menimbulkan rasa penghargaan yang tinggi, memperoleh arti yang terdalam dari pekerjaan yang mereka lakukan, merasa terhubung dan bermakna di tempat kerja, terutama pada karyawan sehingga membuat perasaan kesempurnaan kehidupan batin dan rasa bahagia pada organisasi atau perusahaan tersebut sehingga memiliki kualitas hubungan yang baik dengan orang lain ( Fly LW, 2005:1)

Peneliti berpendapat berdasarkan hasil yang didapatkan terhadap 11 responden dan berdasarkan teori yang ada. Bahwa setelah mendapatkan penerapan spiritual leadership selama dua hari dan diukur kembali selama 3 minggu kemudian didapatkan ada perubahan kenaikan rata-rata terhadap disiplin kerja perawat. Meskipun peningkatan tidak secara optimal.

\section{SIMPULAN}

Kesimpulan dari penelitian ini adalah :

1. Karakteristik responden sebagian besar berumur $31-40$ tahun $54,5 \%$, jenis kelamin responden sebagian besar perempuan 90,9\%, pendidikan responden mayoritas D3 keperawatan 90,9\%, dan lama masa kerja sebagian besar pada klasifikasi 1-10 tahun yaitu $54,4 \%$.

2. Nilai rata-rata kinerja perawat dalam disiplin kerja pada kelompok intervensi sebelum penerapan spiritual leadership adalah 56.27 dengan nilai minimum 52 dan maksimum 61.
3. Nilai rata-rata kinerja perawat dalam disiplin kerja pada kelompok intertervensi sesudah penerapan spiritual leadership adalah 58.36 dengan nilai minimum 55 dan maksimum 62.

4. Ada pengaruh penerapan spiritual leadership terhadap disiplin kerja perawat yang ditunjukkan dengan $p$ value $=0.005<0,05 \mathrm{H} 0$ ditolak, maka ada perbedaan disiplin kerja perawat sebelum dan sesudah penerapan spiritual leadership sedangkan pada kelompok kontrol diperoleh $\mathrm{p}$ value $=$ $0,703>0,05$ sehingga $\mathrm{H} 0$ diterima maka tidak ada perbedaan yang bermakna antara pre dan post pada kelompok kontrol yang tidak dilakukan penerapan spiritual leadership.

\section{UCAPAN TERIMA KASIH}

Pada kesempatan ini, peneliti ingin mengucapkan terima kasih kepada berbagai pihak yang telah membantu terwujudnya penelitian ini :
1. Universitas
Muhammadiyah
Kalimantan Timur
2. RSIA Aisiyah Samarinda

\section{DAFTAR PUSTAKA}

Arifuddin, Napirah (2015). Hubungan Disiplin Dan Beban Kerja Dengan Kinerja Perawat Di Ruang Rawat Inap Rumah Sakit Umum Daerah (RSUD) Undata Palu.

Arikunto, (2010). Prosedur Penelitian Suatu Pendekatan Praktik. Edisi: Revisi. Jakarta: Rineka Cipta Asmaningrum, dkk (2011). Pengaruh Penerapan Spiritual Leadership 
terhadap Komitmen Perawat Pada Organisasi Di Rumah Sakit Islam Surabaya. Tesis dipublikasikan, Program Studi Magister Keperawatan Universitas Indonesia

Astuti, N.K.R. (2012). Keterkaitan Kinerja Karyawan Perusahaan dengan Kepuasan Pelanggan (Suatu Tinjauan Teoritis). Forum Manajemen, Volume 10,no.2.

Dahlan, S. (2014). Statistik untuk Kedokteran dan Kesehatan (Edisi:6). Jakarta: Salemba Medika

Dahlan, M S. (2008). Statistik untuk Kedokteran dan Kesehatan: Deskriptif, Bivariat dan Multivariat Dilengkapi Aplikasi dengan Menggunakan SPS. Edisi: 3. Jakarta: Salemba Medika

Fry, L.W (2008). Spiritual leadership: state of-the-art and future directions for theony, research, and practice. www.tarleton.edu, diperoleh tanggal 15 Desember 2017.

Fry L.W \& Cohen (2008). Spiritual Leadership as a Paradigma for Organization Transformation and Recovery from Extended Work Hours Cultures. Jounal of Business Ethics (2009) 84:265 278, www.springerlink.com, diperoleh tanggal 15 Desember 2017.

Handoko, T.H. 2008, Manajemen Personalia dan Sumberdaya Manusia, Edisi Kedua, Cetakan Keenam Belas, Penerbit BPFF, Yogyakarta

Hasibuan, M. (2005). Manajemen Sumber Daya Manusia. Edisi Revisi.
Jakarta Penerbit PT Bumi Aksara.

Hidayat, A A. (2007). Riset Keperawatan dan Teknik Penelitian Ilmiah. Jakarta: Salemba Medika.

Ian Percy. Going Deep, exploring spirituality in life and leadership. Arizona: Inspired Production Press. Hal 265. (2007)

Ilyas, Y. Kinerja, teori, penelitian, dan penelitian. Pusat Kajian Ekonomi Kesehatan Masyarakat UI, Depok (2002)

Imron. (2010). Kajian Statistik Perspektif Kritik Holistik. Surakarta: UNS Press.

Mangkunegara, A.P. (2011). Manajemen

Sumber Daya Manusia

Perusahaan. Bandung : PT.

Remaja Rosdakarya.

Mardhatillah, dkk (2017). Hubungan

Beban Kerja Perawat Dengan

Pelaksanaan Pendokumentasian

Asuhan Keperawatan Di Ruang

Rawat Inap Penyakit Dalam,

Bedah, Dan Saraf RSUD Dokter

Soedarto Pontianak.

Martoyo, S. (2008). Manajemen Sumber

Daya Manusia. Yogyakarta:

BPFE.

Nursalam. (2011). Manajemen

Keperawatan Aplikasi dalam

Praktik Keperawatan Profesional.

Jakarta: Salemba Medika.

Okavianingsih, I. (2012). Hubungan

Tingkat Pengetahuan Perawat tentang Model Praktik

Keperawatan Profesional dengan Penerapannya di Rumah Sakit Kalimantan Timur Bontang. Skripsi, tidak dipublikasikan, Program Studi Ilmu Keperawatan, Sekolah Tinggi Ilmu Kesehatan Samarinda. 
Rivai, V. dan Mulyadi, D. (2010). Kepemimpinan dan Perilaku Organisasi. Jakarta : PT Raja Grafindo Persada.

Riwidikdo (2013). Statistik Kesehatan. Yogyakarta : Mitra Cendikia Press.

Rizal, Alfi (2015). Hubungan Pelaksanaan Fungsi Manajemen Kepala Ruang Dengan Motivasi Perawat Pelaksana Dalam Memberikan Layanan Keperawatan Di Ruang Rawat Inap RSUD Kota Semarang.

Robbins Judge. Perilaku Organisasi. Jakarta Penerbit: Salemba empat. (2007)

Robbins, Stephen, P. (2007). Perilaku organisasi. Jakarta : PT. Indeks Kelompok Gramedia.

Saiful Anwar (2013). Kepemimpinan dan Transformasi. USIM

Suarli \& Bahtiar. (2009). Manajemen Keperawatan: Dengan
Pendekatan Praktis. Jakarta: Erlangga.

Sugiyono. (2012). Metode Penelitian Kuantitatif Kualitatif dan R\&B. Bandung: Alfabeta.

Sutrisno, Edy. 2011. Manajemen Sumber Daya Manusia. Jakarta : Kencana Prenada Media Group.

Sureskiarti, Enok (2015). Pengaruh Spiritual Leadership terhadap Kinerja Perawat dalam Melaksanakan Asuhan Keperawatan di RSUD Dr. H. Soewondo Kendal. Tesis dipublikasikan, Program Studi Magister Keperawatan Universitas Diponorogo Semarang.

Tobroni. (2010). The Spiritual Leadership. Pengefektifan Organisasi Noble Industry Melalui Prinsip-prinsip Spiritual Etis. Edisi: 2. UMM: Press. 